\title{
Best proximity point theorems for $G$-proximal weak contractions in complete metric spaces endowed with graphs
}

\section{ChalongChai KLANARONG and Suthep SuANTAI}

\author{
ABSTRACT. \\ In this paper, the existence of best proximity point theorems for two new types of nonlinear non-self mappings in \\ a complete metric space endowed with a directed graph are established. Our main results extend and generalize \\ many known results in the literatures. As a special case of the main results, the best proximity point theorems \\ on partially ordered sets are obtained.
}

Acknowledgement. The authors would like to thank the referees for many comments and suggestions to improve the exposition of this paper and the Thailand Research Fund under the project RTA5780007 and Chiang Mai University, Chiang Mai, Thailand for the financial support.

\section{REFERENCES}

[1] Abkar, A. and Gabeleh, M., Generalized cyclic contractions in partially ordered metric spaces, Optim Lett., In Press DOI DOI 10.1007/s11590-011-0379-y

[2] Agarwal, R. P., El-Gebeily, M. A. and O'Regan, D., Generalized contractions in partially ordered metric spaces, Appl. Anal., 87 (2008), 1-8

[3] Al-Thagafi, M. A., and Shahzad, N., Convergence and existence results for best proximity points, Nonlinear Analysis, 70 (2009), 3665-3671

[4] Banach, S., Sur les operations dans les ensembles abstraits et leur application aux equations itegrales, Fundam. Math., 3 (1922), 133-181

[5] Basha, S. S., Best proximity point theorems on partially ordered sets, Optim. Lett., 7 (2013), 1035-1043

[6] Beg, I. and Butt, A. R., Fixed point for set valued mappings satisfying an implicit relation in partially ordered metric spaces, Nonlinear Anal., 71 (2009), 3699-3704

[7] Berinde, V., Approximating fixed points of weak contractions using the Picard iteration, Nonlinear Anal. Forum, 1 (2004), No. 9, 43-53

[8] Berinde, V., Approximating common fixed points of noncommuting almost contractions in metric spaces, Fixed Point Theory, 11 (2010), No 2, 179-188

[9] Berinde, V., Approximating fixed points of implicit almost contractions, Hacet. J. Math. Stat., 41 (2012), No. 1, 93-102

[10] Berinde, V. and Păcurar, M., Fixed points and continuity of almost contractions, Fixed Point Theory, 9 (2008), No. $1,23-34$

[11] Berinde, V. and Păcurar, M., Fixed point theorems for nonself single-valued almost contractions, Fixed Point Theory, 14 (2013), No. 2, 301-311

[12] Bhaskar, T. G. and Lakshmikantham, V., Fixed point theorems in partially ordered metric spaces and applications, Nonlinear Anal. TMA, 65 (2006), 1379-1393

[13] Bojor, F., Fixed point theorems for Reich type contraction on metric spaces with a graph, Nonlinear Anal., 75 (2012), 3895-3901

Received: 24.04.2017; In revised form: 23.01.2018; Accepted: 30.01.2018

2010 Mathematics Subject Classification. 47H10, 46N10, 30L99.

Key words and phrases. Best proximity point, partially ordered set, ordered proximal contraction, proximally orderpreserving, proximally edge-preserving, G-proximal weak contraction.

Corresponding author: Suthep Suantai; suthep.s@cmu.ac.th 
[14] Branciari, A., A fixed point theorem for mappings satisfying a general contractive condition of integral type, J. Math. Anal. Appl., 29 (2002), 531-536

[15] Chatterjea, S. K., Fixed point theorems, C. R. Acad. Bulgare Sci., 25 (1972), 727-730

[16] Derafshpour, M., Rezapour, S. and Shahzad, N., Best Proximity Points of cyclic $\phi$-contractions in ordered metric spaces, Topological Methods in Nonlinear Analysis, 37 (2011), 193-202

[17] Di Bari, C., Suzuki, T. and Vetro, C., Best proximity points for cyclic Meir- Keeler contractions, Nonlinear Anal., 69 (2008), 3790-3794

[18] Eldred, A. and Veeramani, P., Existence and convergence of best proximity points, J. Math. Anal. Appl., 323 (2006), 1001-1006

[19] Espinola, R. and Fernandez-Leon, A., On best proximity points in metric and Banach spaces, Canad. J. Math., 63 (2011), 533-550

[20] Fan, K., Extensions of two fixed point theorems of F. E. Browder, Math. Z., 122 (1969), 234-240

[21] Gabeleh, M., Global optimal solutions of non-self mappings, Politehn. Univ. Bucharest Sci. Bull., Ser. A, Appl. Math. Phys., 75 (2013), No. 3, 67-74

[22] Giannessi, F., Maugeri, A. and Pardalos, P. M., Equilibrium Problems: nonsmooth optimization and variational inequality models, Nonconvex Optim. Appl., 58 (2004), DOI 10.1007/b101835

[23] Jachymski, J., The contraction principle for mappings on a metric with a graph, Proc. Am. Math. Soc., 139 (2008), 1359-1373

[24] Kannan, R., Some results on fixed points, Bull. Calcutta Math. Soc., 10 (1968), 71-76

[25] Nieto, J. J. and Rodriguez-Lopez, R., Contractive mapping theorems in partially ordered sets and applications to ordinary differential equation, Order 22 (2005), 223-239

[26] Nieto, J. J. and Rodriguez-Lopez, R., Existence and uniqueness of fixed point in partially ordered sets and applications to ordinary differential equation, Acta Math. Sin. (Engl.Ser.), 23 (2007), No. 12, 2205-2212

[27] Ran, A. C. M. and Reurings, M. C. B., A fixed point theorem in partially ordered sets and some applications to matrix equations, Proc. Amer. math. Soc., 132 (2004), 1435-1443

[28] Suzuki, T., Kikkawa, M. and Vetro, C., The existence of best proximity points in metric spaces with the property UC, Nonlinear Anal., 71 (2009), 2918-2926

[29] Zamfirescu, T., Fixed point theorems in metric spaces, Arch. Math. (Basel), 23 (1972), 292-298

Center of Excellence in Mathematics and Applied Mathematics

DEPARTMENT OF MATHEMATICS

FACULTY OF SCIENCE

CHIANG MAI UNIVERSITY

CHIANG MAI 50200 THAILAND

E-mail address: chalongchai1001@gmail.com

E-mail address: suthep.s@cmu.ac.th 